\title{
4 Arts, Crafts, and the Education of Arab Women
}

While enjoying the sacrifice of the exquisite Oulad Nails, the polygamist demands that Muslim women be regenerated through work. His wives' daily labor is a nice source of income for him. This is why he snatches up the skilled workers in the marriage market. Isn't it a good investment to pay three hundred francs for a worker-wife who will bring him a thousand francs a year?

Of course beauty is prized in Africa as it is everywhere, but feminine skills are even more appreciated here than they are in civilized countries. For if he is not rich enough to have slaves, the lazy, impractical Arab leaves to his wives the care of weaving his clothes, weaving his mobile home, the tent, preparing his food, which does not only consist of making couscous and honey cakes, but also involves laboriously grinding barley and wheat in a primitive mill made of two stones tightened with a screw, making butter, collecting wood, working the billy-goats' skins, fetching water, tending to the horses and camels, and finally taking down the tent and putting it back up during migrations. These delicate, often exhausted women, who even hold up the stirrup for their lazy husband, go on foot, a child on their back, their arms heavy with food supplies or kitchenware while he lolls on a horse.

The relative comfort or lack of it of a Muslim man depends on his wives' abilities. This is why he does not want them to go to the emancipating school which would remove them from his tyranny, but he is totally in favor of their manual development. This barbarian who does nothing but gaze at his navel is happy to have his wives initiated in skills the products of which encourage his idleness.

But the trades available to Arab women demand, in order to be lucrative, a certain intellectual development. So the man's interest will eventually allay his dread of a school for girls. It is all very nice to make pottery from the soft earth with many colors that is so abundant in Algeria; however, if the Muslim woman could add to the routine that directs her hand some notions that would enlarge her intellectual horizon, the clay she molds would triple in value.

Today, in several regions, Arab women make cups, amphorae, stoves, dishes for baking bread, couscous or meat, and vases of all shapes. They glaze their pottery with a mixture of oil and resin.

Kabyle women not only pull the plough, they also make five-foot high jugs: one of them climbs inside, kneads the clay and gives it the required shape while others take care of the outside. The first woman is pulled out when the vase is completed; it is then put to bake in the sun. Touggourt's residents make wheel-turned pottery. When Arab women will receive vocational training along with an elementary education, they will use kaolin, become expert porcelain workers, and Algerians will no longer have to import their china from France.

Throughout the Algerian territory, native women are working at thousands of looms resembling our former weaving frames; they weave wool, silk, goat and camel 
hair as well as esparto grass and filaments of dwarf palm trees. Before they start weaving, they wash the wool, not with their hands but with their feet, then they spin it, and finally they dye it with extracts of Algerian plants which, like indigo, saffron, and madder, produce colors as bright as they are strong. The more goat and camel hair is mixed with the wool during the spinning, the stronger the woven cloth will be. The felidg ${ }^{78}$ of the tents contains as much hair as wool. The largest width of cloth woven by Muslim women is two meters, the average length six meters.

In the Soûf, five thousand looms work ceaselessly; the women make haiks, rugs, and seventy thousand haoulis ${ }^{79}$ per year are sold on the average for twenty-five francs each. This being so, one understands that the Arab man wants to have flocks of wives making nice profits while he smokes cigarettes and savors mocha. Women from Figuig are also very skilled workers, weaving cotton, wool, and embroidering haiks. Chambaa women weave and embroider cloth. But the most beautiful haiks, white with a thin woolen woof and a silk warp, are woven by Moroccans.

Arab women have no workshops; very ingenious like all daughters of nature, they stick four big stakes in the ground to which they attach wooden cross-pieces that support a ceiling of branches of oleanders, lentisks, or dwarf oaks; the same branches protect the bottom and the sides of this flowered dwelling under which the frame is installed. To work they use only their hands and a small iron tool which they swiftly run on the warp to regularize the weaving. With fine merino wools, Muslim women manufacture haiks and burnouses; for waterproof tents, they join common wools to camel hair and palm-tree filaments to weave one-centimeter thick cloth.

The great pleasure of Arab women is to make carpets of sparkling colors. The Khairas and Yaminas who have a carpet on the loom are heroines in their tribe and in the tent; people come from far to admire and appraise their work. It seems that the charming Muslim weavers are the ancestors of the Aubusson weavers. The industry and manufacture of carpets is said to have been imported to Europe by the Arabs who conquered Spain and invaded France. The Aubusson factory might owe its creation to one of the Arab tribes conquered by Charles Martel around Poitiers in 732.

There are women who know only how to weave, others how to execute the drawings; so the former buy the talents of the latter for one franc a day during the three weeks that the carpet is on the frame.

The manufacture of carpets today suffers from competitors in metropolitan France, specifically in Lyon and Nîmes. Despite that, Arab thick-pile carpets from the region of the plateaus are so much in demand that a native vocational school was created in Algiers by Mme Delfau to manufacture them. This school, which receives encouragement and subsidies from the administration, trains monitors who then teach the women of their tribe to make carpets for the Europeans' tastes while keeping their

78 Saharan fabric woven mainly from camels' manes.

79 A haouli is a long piece of fabric woven with wool and used as a turban, a rug, or a tapestry. 
original character. For the Moorish carpets to be as popular on the European market as are Indian and Persian rugs, it will suffice to channel the manufacturing women's artistic sense, to teach them to show their originality, to give them, by developing their intellect, the key to better understand and reproduce the emblems and symbols that constitute Arab art.

In the Fezzan, women from Gatroûn make pretty baskets which are exported in all neighboring oases. Ghadamesians embroider leather with inimitable talent. Women from Agadès weave mats and make interesting leather objects. Cheeses made by women of the Aïr are famous throughout the Sahara. Women of Ouargla, Negresses mostly, make the mdal, big straw hat adorned with small silk squares of all colors, worn by Arabs over their turbans or chéchia. Another Algerian specialty is embroidery on silk or on so-called oriental baptiste.

In Algiers, when Mme Luce, ${ }^{80}$ founder of one of the first French-Arab girls' schools, was forced by the Conseil général to transform her institution into an ouvroir, she taught young Moorish girls to create original embroidery, sometimes simple, sometimes sculpted like lace, as evenly as if it were made by machine. From 1862 to 1878, the Luce vocational school was supported by a grant of the Bureau of Muslim Aid amounting to 1800 francs a year and an odd and vast house for living quarters. In 1878, house and subsidy were taken away; Mme Luce Ben-Aben, Mme Luce's granddaughter and successor, had to conduct in her apartment - where it was impossible to receive many pupils - this teaching that gave so much to art and the French motherland. Foreign winter residents pay good money for this embroidery which they carry away as souvenirs of African industry. Visitors to English and American exhibits admire it; French exhibits give it a gold medal. But how many French and Algerians ignore the existence of this artistic embroidery with its Arab themes?

Mme Luce should be praised for opening her pupils' mind as well directing their hands. While exposing them to the refinements of artistic embroidery and teaching them to follow or trace a drawing, a figure, or a cabalistic sign, she secretly teaches them to speak and write French. I have had in my hands letters written by these young Mauresques that a Parisian school girl would not have to be ashamed to sign.

As soon as they are educated and aware of our mores, Arab women become unwilling to accept polygamy. They prefer to prostitute themselves than marry a polygamist. This instinctive repulsion proves that polygamy does not bring happiness to the female sex. A creature kept for profit condemned to the ceaseless toil of a mercenary or a creature of luxury doomed to the perpetual immobility of a mummy laying on cushions, the Arab woman, whatever her condition, in a house or in the tent, is not interested in the details of domestic life. She neither feels nor is at home in her husband's abode.

80 Came to Algiers shortly after the conquest; she opened a school for Arab girls in 1847, pledging that she would not instill her own religion. 
However, some Mauresques sometimes have, like European women, modest culinary talents. They make honey cakes, gold, sweet, and transparent flaky pastries that the administrators find delectable. They methodically work barley flour to obtain granules which, steamed in chicken or lamb consommé and generously basted with a very spicy gravy, make up the famous couscous. Most often it is the husband who prepares the couscous because the wives who do not have servants to do it either do not know how to cook or cannot be taken away from their work, a work that would be profitable if, instead of being accomplished without training, it were done with a method acquired through a rudimentary education.

The Arab woman, whose skills are weaving, common pottery, basketry, as well as leather, velvet, silk and artistic embroidery, needs a certain intellectual development to be able to earn a living from her work. And although this intellectual development prevents her from accepting the customs of her race and the whims of polygamists, she should still receive it because, in Algeria as in France, life depends on couscous or bread, not prejudice.

\subsection{The making of a Muslim Female Physician}

How could the Arab woman be more enlightened, more refined, and qualified to perfect her skills to make them more profitable as long as there are no schools where she could be taught? During my stay in Algiers, I was surprised to find out that Algeria's capital had no schools for native girls. The following is what happened.

A former resident of Algeria had conceived the plan to have, at her own expense, a Mauresque initiated in the art of healing. She wanted the new doctor, once she had received her diploma, to keep the costume and customs of her race in order to inspire confidence, and to devote herself to ease the ills of women, her compatriots and co-religionists. Since this commendable objective would help liberate the Arab woman, I started to look for a young Moorish girl whose intelligence would qualify her to profit from medical studies. Thinking that nowhere better than in her school would I be able to get information about the aptitude of a nine or ten-year old girl, I asked where to find the Arab schools for girls. Several people gave me answers that proved they did not understand what I was asking for; then remembering the zawayas (schools maintained by mosques) I walked toward the Place du Gouvernement and entered the grand mosque, so prettily illuminated at the end of Ramadan by sparkles of studded emeralds (simple green Chinese lanterns). The taleb (scholar) I spoke to also seemed surprised by my question. He thought for a long time and finally assured me there were no Arab schools for girls in Algiers. 
"Has there ever been one?"

"Yes."

"Are there any somewhere else?"

"Yes."

Well, asking one question after another, I succeeded in learning the name of an exdirectress of Algiers' schools for Arab girls, and after much back and forth the address of her granddaughter who told me many things; but I wanted to check everything out.

In search of precise and exact information I scanned official documents in libraries, I read the reports of general councils and everything relating to public education since the annexation. I learned that before the decree of July 14, 1850 that organized Muslim teaching and created in Algiers, Oran, Constantine, and Bône schools where Arab girls received a primary education, there was a school for Muslim girls in Algiers; however when France took away the habous ${ }^{81}$ holdings on which it subsisted, it had to close its doors. In its session of 1861, the Conseil général of Algiers took away the allowance intended for Arab girls' schools, asserting that pedagogical teaching did not suit the women's condition in Muslim society and that it could not be reconciled with the duties and mores imposed on women by Muslims. Educating them would therefore do young girls a disservice; no self-respecting Muslim would send his daughter to school or take a wife there, because it was well known that when young girls had gone to school they were less flexible and did not easily accept the customs of their race. ${ }^{82}$

No schools, consequently no students. So I had to contact families directly to find the person I was looking for. I approached several families who were quite willing to sell their little girls to a man, but refused, despite offers of compensation equal to a dowry, to entrust them to me to be educated. While these steps were fruitless with regard to my objective, they were very profitable to my curiosity and my research on the habits and customs of Arabs.

In all human societies, the rich class holds more prejudices than the less rich. I thought my proposition's only chance of acceptance was by the poor; so I knocked at the door of the Bureau of Muslim Aid. The treasurer, who had seen a young Muslim woman be successfully educated, seemed willing to help me find the future doctor. He mostly saw the humanitarian aspect of the question; as for assimilation, he had lost hope, he said, and compared Muslim fanaticism to that of Saint Louis ${ }^{83}$ who spoke of driving his sword to the hilt in the unbeliever's body. But education kills fanaticism, and the French who really want to conquer Arab fanatics would do well to imitate

81 Collective inalienable assets; charitable and religious foundations, or property belonging to religious institutions.

82 Mohammed Kamal, editor for the newspaper Le Mobacher, forcefully demands education for Arab women. (author's note)

83 Pious king of France from 1226 to 1270. 
Egypt's viceroy Mahomed-Ali who had children picked up in the streets and public squares to take them to school. That is how he reformed his country.

However, time was going by and we had not yet chosen a poor girl. It was important to find a child who could at least read and speak some French. I contacted everybody everywhere; no need to describe the vain searches, disappointed hopes, the right child found and lost numerous times before being discovered. Finally, I went to the principal of the Académie d'Alger. M. Jeanmaire declared himself in favor of the idea of educating a Muslim girl. He advised choosing a Kabyle and kindly offered to find an intelligent child. She should be sent to study in Paris because, if she stayed in Algiers, Arabs would not have as much consideration for her as if she came back from France. Her education should be facilitated, obstacles waived, and she would graduate as a health officer. Her example would encourage other Arabs to enroll their daughters in medical studies and motivate the government of the Republic that furnishes Arab physicians, who receive remuneration as colonization's doctors, to do the same for women. Furthermore, it would cost less: girls assimilate right away whereas it takes boys four years.

My abrupt departure from Algeria inevitably adjourned the plan to have a Muslim woman become a doctor. But the idea will be taken up again before long; I am certain the girls of our North Africa will not be reluctant to choose serious studies.

It is urgent, as much from a patriotic as from a humanitarian point of view, to have Muslim women doctors, because the English octopus is trying to squeeze our beautiful colony in its tentacles; after providing arms and powder to belligerents and bandits in order to "do us in" in Algeria's chaos and troubles, it is trying to conquer the country morally. It is sending to Arab tribes legions of alleged women doctors who, under the pretext of treating Muslim women and giving them medicines, enter the tents to disparage and slander France while vindicating England. When these deaconesses are thrown out, they come back as winter residents. ${ }^{84}$

\subsection{Algiers without Arab Schools for Girls}

The two thousand Arab or Kabyle little girls scattered in the French schools of Algeria's territory give the lie to those who affirm that the natives are incapable of benefiting from the education given to them. These young Muslim girls not only show remarkable intellectual abilities, but at the end of the school year their parents have every right to be proud of their accomplishments, for they successfully pass the exams and come away with prizes.

These guarantees of intelligence have not decided the rapporteurs for Algeria's budget to propose educating Arab girls: "No school for them," they say, "they would

84 Who were mostly English; Algeria had become a favorite tourist destination for the British due to its climate. 
be déclassé.” Schooling has the same effect in France as in Algeria: by morally elevating those who received it, it removes them from their social class and creates needs. Would one want to suppress education and halt progress just to avoid the difficulty of a short transition? No one thinks so. Everyone agrees to organize society better so that an educated humanity can satisfy its needs.

A wish has been expressed in the Conseil général of Algiers in favor of the creation of a vocational institute for Muslim girls; but Arabophobes ${ }^{85}$ together with Arabs seated in that assembly, have recognized that this would lead to the opening of a school for girls, and voted it down. "Girls coming out of school," exclaim the terrified Algerians, "would no longer want to be sequestered!" Yet it is this sequestration of women that keeps men under the yoke and makes them an easy prey. The city of Algiers, inhabited by many natives, is thus deprived of schools for native girls because of the whim of enemies of the union of the French and Arab races.

It is absolutely impossible for young Muslim girls who cannot attend French schools for lack of knowing French to get an education in Algeria's capital. But we are working for them. We have petitioned the authorities, pointing out that Arab girls should not be condemned to greater ignorance in 1900 than between 1845 and 1861 when they did have schools.

The French, who dare to argue that, on account of the statutes, Arab girls escape us when it comes to education and that we have to respect Muslim inheritance laws that despoil them of their heritage, should confess that it is in their interest to authorize Islamic tyranny because women's ignorance opens the way to exploiting the entire native race. When a Muslim woman, who is only entitled to a third of her father's inheritance, has no male co-inheritor, France takes the other two thirds. No law sanctions this despoliation of the Arab woman; the established custom rather resembles a tacit agreement between thieves when the French appear to say to the Muslims, "We shall let you rob your women provided that we shall rob them when you are not there!” The French Government cannot continue to give the example of thievery by taking the Arab girls' wealth or allowing it to be taken.

The rapporteurs for Algeria's budget who are asking for a decrease of boys' primary schools are not surprised, of course, that cities like Algiers and Oran are deprived of Arab schools for girls; on the contrary they are quite ready, like simple Muslim jailers, to denounce the danger of a school that will emancipate girls. Because having women read seems as inappropriate in Algeria as having them vote is in France. Everyone praises the benefits of education, but refuses to spread it throughout Arab society.

Yet it could be done at little cost if, instead of creating entirely new and expensive schools for Muslims only, access to existing French schools were facilitated for native girls and boys by hiring male and female Arabic-speaking teachers to assist the directors and directresses of these schools.

85 Author's italics. 
Would children, playing the same games, competing with each other and working hard together, not nip in the bud the ridiculous prejudice of race that makes us believe that our superiority of education is tantamount to an inborn superiority? Even in centers where few Europeans have settled, all that would be needed are French-Arab schools. Why confine the natives, whom we want to assimilate, to schools exclusively reserved for their race? Is it by separating children that we shall succeed in uniting adults? Consequently, there should be no religious teaching in school; instead of respect for Muslim beliefs - which would encourage keeping these beliefs - there should be neutrality, indifference toward the pupils' different religions.

Contrarily to those who demand fewer Arab primary schools, I, having lived for four years among the natives as a curious investigator, I shout, "Schools, more schools!" We complain that Arabs stay untouched by our civilization, but we refuse to teach them what we reproach them for not knowing! What would be the excuse for the conquest if the Arabs we have subjugated in order to civilize them (sic) continue to live in a state of nature?

Assimilation would be near, if not already done if, in the memorable debate that took place in the Conseil général of Algiers in 1861, the Algerians had not quietly allowed the Arabs who abhor the emancipating schools for Muslim girls describe these schools as imitations of Athens' and Corinth's gynoecia and take advantage of their number to vote their closure. Because the women, easily won to our civilization, would have strongly helped us to win over the Arabs and to provide us with contacts in the Muslim world.

The shrewd natives know very well that the bell of the common school for French and Arabs would ring the knell of their resistance to assimilation. Consequently, they are hostile to mandatory education for boys and unamenable to any woman's intellectual development: "If our women were educated," say the Muslims, "they would become allied with Christians." So let us no longer ask them in the municipal or general councils whether it is opportune to open schools for native girls since we know in advance that the response will be negative.

The male sex is always and everywhere decided to smother the female sex; that is why it is necessary that each and everyone, man and woman, have the right to intervene on his or her own behalf in administrative or legislative assemblies.

For us French, our interests in Algeria should take precedence over everything. Now, we have a real interest, a political interest, in educating Muslim women, ${ }^{86}$ for they would help us overcome prejudices and make Muslims happy despite themselves. The Arabs will be very happy if, thanks to us, their wives have some intellectual culture. Witness these words of the ex-rebel chief Kada to a French woman whose renown had preceded her in Laghouat: "As for me, I only have a stupid wife... Your husband is lucky to have you! Where did he find you? If I had had a wife like you who

86 Author's italics. 
understands everything and knows everything, I would have become the great Sultan of France!”

\subsection{Adornments, Costume, African Women's Art of Being Beautiful}

One pretends to fear the polygamists so as to avoid educating Muslim women, their chattel, even though it is more than a half century since Général Bugeaud said, "Arabs elude us because they conceal their women from our eyes."

Far from taking these words into account, one government after another since Algeria's conquest allowed the Arabs to sequester and veil their women; and didn't a minister of Justice recently positively forbid Algerian lawyers to ask Muslim fiancées to lift their veil during the signing of their contract? And a more recent memorandum ordered examining magistrates and criminal investigation officers to keep native women veiled in their offices. This homage to the Koran favors falsehoods and substitution of persons. This is how a young woman named Kheira could recently pass for an old one named Kheltoum in front of an attorney in Orléansville; this substitution permitted a son-in-law to appropriate his mother-in-law's property.

The daughters of noble tents are veiled at the age of six. They are tattooed around their fifth birthday like girls of all conditions. Beauty spots, little flowers, small crosses adorn their face, nicely accentuating the whiteness of their skin. Each tribe has its own mark and an assigned place for it; it is like a coat of arms that distinguishes from afar those whom it adorns. In Algiers, when an Arab dies in the street, there is always someone in the crowd who recognizes by the tattoo the tribe to which he belongs.

Muslim women have been taught to believe that the woman whose face is seen is somewhat dishonored, so while their bare body might appear through the gap in their peplum, they carefully hide their nose. They are not allowed to leave their house any more than to show their face.

"What do you mean! There are women in the streets of Algiers!"

"Yes, but they are not refined Muslims, they are prostitutes or licentious women."

Mohammed, a very jealous husband, wanted to guarantee the virtue of his seventeen wives and therefore dictated that all Muslim women be veiled and not seen by strangers. This precept, followed a little more loosely in the countryside, is rigorously respected in the cities; this is why women detest the cities which they rightly consider as tombs where their life behind walls is plagued by physical infirmities as well as moral subjection.

In and around Algiers, women hide their face behind a sort of mask made of a handkerchief showing only their handsome eyes. They are not hindered by skirts. Under the haik, they wear baggy, puffed, very long, nearly always white pants and a pretty light silk vest that suits them very well. Under the haik, jauntily perched on their long black tresses, is a little cap tinkling with coins from which escapes their naturally curly hair. 
Women from Laghouat all wear a costume that, even if made of rags, is very theatrical. This costume, kind of an ancient peplum, is open on the sides and held on the shoulders by massive silver pins; a long raised floating veil is tied below the neck and comes down in a train to form a cloak. On their head, they wear a regal headband.

Women from many regions are dressed almost exactly like the Madonnas of our churches. They wear nothing sewn because they do not know how to work a needle as Europeans do. They wear the melhfa, made of a seamless piece of white cloth - wool, calico, or muslin - draped around their body and tied on the shoulders or attached with a silver pin adorned with gems. Their arms, heavy with bracelets, emerge from this dress; their bare breasts are visible from the side, breasts usually so thin there is no indecency in showing them. The melhfa is tightened at the waist with a brocade belt or a skein of multicolored wool.

As a belt, rich Muslim women wear a twenty-centimeter wide silver breast-plate. With their head and neck chains, their bracelets and anklets, they produce a metallic sound when they walk, a kind of sword rattle or spur clangs which make these houris sound like men-at-arms.

Jewels are an integral part of clothing; Arab women wear them every day. Necklaces are displayed on their chest deformed since childhood by their mother who pulled on their breasts to lengthen them to the waist. Their headdress is half turban, half miter. A golden silk scarf envelops the head on which sparkles a diadem incrusted with gems; attached to this wrapped scarf and bound by a cameo, are gold and silver chains holding huge and heavy earrings. Without these chains, the enormous set of jewels made of coral plates and rings embedded in solid gold or silver would cut their ears within an hour. O Sarah! When to take revenge on your rival Hagar for having seduced Abraham you had her ears pierced, could you have guessed that all these women would want to bear the shameful mark you inflicted on your slave and hang car wheels there as ornaments? There are earrings measuring thirty centimeters in diameter! These crude jewels are made by itinerant merchants who go to the villages, melt the duros given to them, and transform them into necklaces and bracelets according to the wishes of their owner.

Muslim women in nearly all regions wear the haik, a long white veil; they modestly bring it to their face with their hand when by chance they go out to ride in a kind of prison-car with drawn curtains.

Saharan women, all of them pretty, wear white, blue or red clothes; they wear a melhfa and to go out put on a coat called ghansa. For jewelry they have a necklace made of coins, grains of coral, and cloves. Their earrings fall to their shoulders.

The handsome, Greek type, Ghadamesians wrap themselves in a piece of cloth that passes under the right arm, attaches on the left shoulder, leaves one breast bare, and is held to the body with a red belt. A white scarf floats around them giving them a vaporous and ethereal look. Their gold or bronzed diadem holds a big red pompom hanging in the middle of the forehead, symbol of the freedom forbidden to slaves. On their feet they wear richly embroidered red leather shoes. 
The Chambaa women have a sleeveless gandura, open on the side; their black curly hair escapes from their turban and falls on their shoulders; they are not veiled. The women from the Touat do not wear any veil either. The mixed-blood Tuareg women are clothed like their husbands in goat skins and dirty haiks; their hair, never combed, is untidy. The pure race Tuareg women are very beautiful; they only veil their face in front of strangers as a token of respect.

"The remedy to poverty is Sudan," says an Arab proverb. The Sudanese women, with unraveling cloth and rows of strung shells hiding their nudity, do not reveal wealth. The Negro Koholanes, neighbors of Sudan, have as only clothing the fouta (handkerchief knotted on the hips); others wrap themselves in a piece of blue linen one end of which serves as a headdress that shows only the earrings. The women from Fulani too wrap themselves in a piece of cloth, but do not hide their handsome hair that falls on their shoulders in heavy woolly tresses adorned with glass, shells, and brass. Large earrings made of five or six rows of coral, glass, and unusual seeds are striking against their face's golden skin, and large oudâa, ${ }^{87}$ amber, or clove necklaces roll on their chest, attached by a bright red silk strip passing between the breasts and ending on one of the hips. This get-up contributes more than a little to make them pretty.

Like the costumes, modesty varies from country to country. In Egypt, women bare the breast and veil the face. Kabyle women do not subject themselves to Arab customs; under their small black headdress they keep their face uncovered and freely go out like Europeans; their short melhfa exposes their bare legs adorned with bracelets on the calves and ankles.

In every Muslim headdress is nested a small mirror, accessible and apparent, which women use to put on the kohl that gives brilliance to their eyes, accentuates the arcs of their brows, and shades their lashes. The women from the Tell and the Sahara, like those of the South, enlarge their eyes with kohl. Even Negresses use kohl which, among other properties, has that of stopping tears. It is said that those using it acquire a clear and piercing sight. It is known that the basis of kohl is antimony trisulfide; Mohammed orders to use it and Arab doctors prescribe it. Arab women also use henna to redden their cheeks, lips, toe and finger nails; the poets say it makes them look like fruit of the jujube tree.

Everywhere the women's neck and chest are adorned with necklaces made of glass, coral, gold sequins, and cloves; their face is decorated with small blue drawings that accentuate their golden, creamy, pearly, or luminous skin. Their red mouth often conceals dazzling pearls.

The Arab woman walks with small steps, chewing the $s w a k^{88}$ that perfumes her breath, makes her lips purple, and her teeth shiny white. One sees at the same time

87 Small shells used as money in sub-Saharan Africa, they sometimes alternate in necklaces with coral, silver pieces and cloves.

88 Natural bark of the bush of the same name. 
the movement of her feet and the swaying of her hips; she proudly arches her waist; a strange seduction - of which she is well aware - emanates from her whole person.

Winter and summer she wears the same clean or dirty white costume, with or without a colored sheer layer. At night, if she is not rich enough to sleep on a carpet or a mat, she simply lies down, lightly clothed, on the bare earth.

Why is she prevented from wearing a burnous which would envelop her so usefully, just as the French woman is prevented from wearing pants which would make her three times more agile? Mohammed forbade her to wear a burnous because, with this cloak, "women would be able to have a life outside and would cheat even more often on their husbands." But even without the burnous, they have no qualms about doing it. The Arabs sadly confess that their companions, unlike European women, do not get attached to their husbands.

Is the Muslim woman's heart this indifferent? Or is she not taking revenge by her deliberate coolness and her calculated coquetry for being, like cattle, an object of traffic?

Be that as it may, her thinly covered chest is very sensitive to the cold. Who knows how many pretty Moorish women are laid to rest on the Algerian plateaus every winter? If prejudice is torture in civilized countries, it can be said that in barbarian countries prejudice kills. 